\title{
"The effect of board governance and debt policy on value of non-financial firms"
}

\begin{tabular}{|c|c|c|}
\hline AUTHORS & \multicolumn{2}{|c|}{$\begin{array}{l}\text { Zainal Abidin Sahabuddin } \\
\text { Bram Hadianto (D https://orcid.org/0000-0001-9140-3216 }\end{array}$} \\
\hline ARTICLE INFO & \multicolumn{2}{|c|}{$\begin{array}{l}\text { Zainal Abidin Sahabuddin and Bram Hadianto (2019). The effect of board } \\
\text { governance and debt policy on value of non-financial firms. Investment } \\
\text { Management and Financial Innovations, 16(2), 37-46. } \\
\text { doi:10.21511/imfi.16(2).2019.04 }\end{array}$} \\
\hline DOI & \multicolumn{2}{|c|}{ http://dx.doi.org/10.21511/imfi.16(2).2019.04 } \\
\hline RELEASED ON & \multicolumn{2}{|l|}{ Wednesday, 17 April 2019} \\
\hline RECEIVED ON & \multicolumn{2}{|l|}{ Monday, 03 December 2018} \\
\hline ACCEPTED ON & \multicolumn{2}{|l|}{ Friday, 29 March 2019} \\
\hline LICENSE & \multicolumn{2}{|c|}{$\begin{array}{l}\text { This work is licensed under a Creative Commons Attribution } 4.0 \text { Internationa } \\
\text { License }\end{array}$} \\
\hline JOURNAL & \multicolumn{2}{|c|}{ "Investment Management and Financial Innovations" } \\
\hline ISSN PRINT & \multicolumn{2}{|l|}{$1727-7051$} \\
\hline ISSN ONLINE & \multicolumn{2}{|l|}{$1810-5467$} \\
\hline PUBLISHER & \multicolumn{2}{|c|}{ LLC "Consulting Publishing Company "Business Perspectives" } \\
\hline FOUNDER & \multicolumn{2}{|c|}{ LLC "Consulting Publishing Company "Business Perspectives" } \\
\hline $0^{\circ}$ & 15 & $\begin{array}{l}\text { ニここ } \\
\text { ニ泣 }\end{array}$ \\
\hline NUMBER OF REFERENCES & NUMBER OF FIGURES & NUMBER OF TABLES \\
\hline 37 & 0 & 7 \\
\hline
\end{tabular}

(c) The author(s) 2022. This publication is an open access article. 


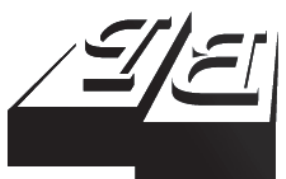

BUSINESS PERSPECTIVES



LLC "CPC "Business Perspectives" Hryhorii Skovoroda lane, 10, Sumy, 40022, Ukraine

www.businessperspectives.org

Received on: $3^{\text {rd }}$ of December, 2018 Accepted on: 29 th of March, 2019

(C) Zainal Abidin Sahabuddin, Bram Hadianto, 2019

Zainal Abidin Sahabuddin, Dr., Faculty of Defense Management, Department of Defense Economics, Indonesia Defence University, Indonesia.

Bram Hadianto, Dr., Faculty of Economics, Department of Management, Maranatha Christian University, Indonesia.

\section{() (i)}

This is an Open Access article, distributed under the terms of the Creative Commons Attribution 4.0 International license, which permits unrestricted re-use, distribution, and reproduction in any medium, provided the original work is properly cited.

\section{THE EFFECT OF BOARD GOVERNANCE AND DEBT POLICY ON VALUE OF NON-FINANCIAL FIRMS}

\begin{abstract}
Supervisory board plays an essential role to implement good governance in firm. If this governance is implemented well, the increase in firm value will occur. Related to this statement, the main question that appears is about the number and independence rate of supervisory board members needed to enhance firm value. Besides supervisory board, debt policy holds an important role for firm because of bankruptcy issue. Firm with good governance tries to avoid this issue by decreasing the amount of its debt to create high value.

The aim of this study is to test and analyze the effect of board governance, consisting of size and independence of supervisory board, and debt policy on value of non-financial firms forming the Kompas 100 Index on Indonesia Stock Exchange. To be able to generalize results on all non-financial firms forming this index, stratified random sampling method is used to take firms as the sample from the population. Method of data analysis used is fixed effect regression model.

This study infers that the number of supervisory board members has no effect on firm value, whereas board independence and debt policy have the effect on firm value: firm with high portion of supervisory board independence and the amount of debt significantly tends to have low value.
\end{abstract}

Keywords

JEL Classification

debt policy, firm value, supervisory board independence

\section{INTRODUCTION}

Governance is mandatory for capital market-listed firms to be implemented. It is due to the protection issue of two groups of stakeholders: investors and creditors. By implementing corporate governance well, creditors and investors will get that certainty that profits becoming their right will be fully back to them by stockholders acting as firm controller (LaPorta et al., 2000).

One of implementations of corporate governance in listed firms on capital market can be shown by the existence of supervisory board. The name of board supervising depends on its system. In single board system, used by firms in the United States of America, United Kingdom (Tjager et al., 2003) and Bangladesh (Rashid, 2018), board of directors is the supervisor of top managers (see Gitman \& Zutter, 2012). In double board system, board of commissioners is the supervisor of board of directors (Sukamulja, 2002). The examples of countries using this system are Denmark, Japan, the Netherlands (FCGI, 2001), Germany (FCGI, 2001; Kim \& Nofsinger, 2007). Besides the names of the countries mentioned before, Indonesia is one of the countries adopting double board system (FCGI, 2001; Sukamulja, 2002; Tjager et al., 2003). This condition happens, because Indonesia adopts Dutch law system (FCGI, 2001). 
In many previous studies, the supervisory board is always related to firm value through its size and independence. Unfortunately, there is no consensus from the study results that can be reached about the effect of board size on firm value. The study result of Isshaq et al. (2009), Waterings and Swagerman (2011), Badu and Apiah (2017) shows that the more members of supervisory board, the higher the firm value, whereas the study of Yermack (1996), Eisenberg et al. (1998), Gill and Mathur (2011), Ibrahim and Salihu (2015), as well as Nath et al. (2015) indicates that the firm with small supervisory board is able to significantly increase the firm value. In addition to the study results showing the effect, the study of Yammeesri and Herath (2010), Kritika and Choudhary (2015) denotes that the size of board has no effect on firm value.

In fact, the inconsistent results are also available among the studies focusing on the impact of board independence on firm value. For examples, the study of Setiadi et al. (2017) shows a positive effect. On the contrary, the study of Ningtyas et al. (2014) and Rashid (2018) exhibits a negative effect of board independence on firm value. Differing from the study presenting the positive and negative effect, the study of Isshaq et al. (2009) proves that board independence does not have the effect on firm value. In line with Isshaq et al. (2009), the result of the study done by Yammeesri and Herath (2010), Kangarlouei et al. (2013) and Nath et al. (2015) explains that firm value is not affected by board independence.

Similar to the effect of supervisory board on firm value, debt policy implemented by firms also has contrary effects on firm value creation. Based on the previous studies, the result can show positive effect (see the study of Isshaq et al., 2009; Yammeesri and Herath, 2010; Setiyawati et al., 2017), negative effect (see the study of Paminto et al., 2016) and no effect (see the study of Sambora et al., 2014; Gunarso, 2014).

These ambiguous results of studies about the effect of supervisory board size, board independence, and debt policy on firm value motivate this study to be conducted by utilizing firms from non-financial sectors forming the Kompas 100 Index. The use of these firms is due to a quick movement of price leading to creation of value for investors buying their stocks.

The purpose of this study is to test and analyze the effect of board governance and debt policy on value of non-financial firms forming the Kompas 100 Index on Indonesia Stock Exchange. The next parts of paper are organized into four sections: section one presents the conceptual framework and hypotheses development, section two displays the research method, sections three and four describe the results and discussion. Final section shows the conclusion and recommendations based on the results from this study.

\section{CONCEPTUAL} FRAMEWORK AND HYPOTHESES
DEVELOPMENT

\subsection{The effect of supervisory board size on firm value}

Theory of agency states that firm with small size of supervisory board will have high market value, because the members in the small board are able to easily organize, interconnect, and take a decision (Lipton and Lorsch, 1992). This argument is confirmed by the result of the studies of Yermack
(1996), Eisenberg et al. (1998), Gill and Mathur (2011) stating that the small size of board causes firm to own high value. Based on this information mentioned before, the first hypothesis is formulated as follows:

H1: Firm with big number of supervisory board members tends to have low value.

\subsection{The effect of board independence on firm value}

Independence of supervisory board is labeled by outside members of board without special relationship with firm managers and controlling stockholders (Yammeesri and Herath, 2010). The duty of 
independent board members is to monitor board of directors or top managers to protect the interest of public stockholders (Tjager et al., 2003). This condition leads to the increase in firm value in capital market (Setiadi et al., 2017). This explanation has been already confirmed by Setiadi et al. (2017). Based on this information, the first sub-hypothesis of hypothesis 2 can be formulated as follows:

\section{H2a: Firm with high board independence tends to have high value.}

On the other hand, agency theory, cited by Mishra and Kapil (2018), states that the large number of outside members of the board will make firm value go down, because they cannot align with top managers. Instead, the large number of inside supervisory board members is desired to align interests between them, so that the high firm value can be attained. This explanation is confirmed by the studies of Ningtyas et al. (2014) and Rashid (2018) confirming that board independence has a negative effect on firm value. Based on this information, the second sub-hypothesis of hypothesis 2 can be formulated as follows:

\section{H2b: Firm with high board independence tends to have low value.}

\subsection{The effect of debt policy on firm value}

According to trade-off theory, the use of debt can cause a change in a market value of firm. Market value of firm will go up if the firm gets benefits of tax shield when it uses more amount of debt (Brealey et al., 2006). The explanation of this positive effect has been already supported by Isshaq et al. (2009) and Setiyawati et al. (2017). Based on this information mentioned before, the first sub-hypothesis of hypothesis 3 can be formulated as follows:

H3a: Firm with high portion of debts used to finance assets tends to have high value.

Besides making the increase in value of firm, use of excessive debt can make value of the firm go down. The condition indicates the financial distress (Brealey et al., 2006), where firm is not able to fulfill its promise to creditors based on their debt agreement con- tract (Sugiarto, 2009). If this condition is not immediately handled, firm will go bankrupt (Brealey et al., 2006). The explanation of this negative effect of debt on market value has already been supported by the result of the study of Paminto et al. (2016). Based on this information mentioned before, the second sub-hypothesis of hypothesis 3 can be formulated as follows:

H3b: Firm with high portion of debts used to finance assets tends to have low value.

\section{RESEARCH METHOD}

This section explains the type of the study, definition of variable operationalization, description of population, sample, and sampling method, way to collect and analyze the data.

\subsection{Type of study}

Based on the research design classification and relationship of variables, explained by Hermawan (2006), the type of this study is hypotheses testing and is able to be classified as causal study.

\subsection{Definition of variables operationalization}

This study uses two types of variables: dependent and independent variables. Acting as dependent variable is firm value (FV). According to Hanafi (2017), value of firm listed on capital market is measured by stock price. In this study, stock price of firm used is in logarithm. Acting as independent variables are supervisory board size (BS), board independence (BI) and debt policy:

- BS is measured by the size of the board of commissioners containing the members and president of the firm at the end of the year;

$\mathrm{BI}$ is measured by the ratio calculated by dividing the number of independent members of the board of commissioners by the size of the board of commissioners of the firm at the end of the year;

debt policy is measured by debt to total asset ratio of the firm (DAR) at the end of the year. 


\subsection{Population, sample, and sampling method}

Jakarta Stock Industrial Classification explains that all listed firms on Indonesia capital market are classified into three sectors. The first sector consists of firms in extractive business. The second one consists of firm in manufacturing business. The third one is firms in service business (IDX Fact Book 2016).

In this study, we use the firms forming Kompas 100 Index from 2010 to 2015 as the population. Based on our observation, the firms becoming this Index constituents consist of three sectors as explained before. Therefore, we treat the sectors as the strata so that the suitable sampling method is stratified random sampling. The use of this sampling method is due to generalization of result.

Because not all non-financial firms becoming population exist during that period, we set sampling frame to get the relevant population based on their availability. Based on this rule, the number of relevant population is 40 firms. To obtain the number of firms as sample $n$ representing the number of relevant population $N$, the Slovin formula is used with margin of error $e$ of $1 \%$. Moreover, this formula cited from Suliyanto (2009) can be seen in the first equation as follows:

$$
n=\frac{N}{1+N e^{2}} \text {. }
$$

Based on this formula, the number of sample $n$ is $40 /(1+40(1 \%)(1 \%))=28.57 \approx 29$ firms (rounded). After the number of firm is determined, the next step is making allocation of the number of population to the number of sample, where the final result of this process can be seen in Table 1.

Furthermore, 29 firms as sample are taken from their population randomly. To make the random process of taking firms as sample happen, we use random number generated by Microsoft Excel as
Hartono (2012) states. After that, the names of firm as sample from three sectors can be obtained:

- from primary sector, the firm names are: (1) Aneka Tambang (Persero) Tbk. (ANTM), (2) Eagle High Plantation Tbk. (BWPT), (3) Energi Mega Persada Tbk. (ENRG), (4) Vale Indonesia Tbk. (INCO), (5) Indo Tambangraya Megah Tbk. (ITMG), (6) Timah (Persero) Tbk. (TINS), (7) Tambang Batubara Bukit Asam (Persero) Tbk. (PTBA);

- from secondary sector, the firm names are: (1) Astra International Tbk. (ASII), (2) Charoen Pokphand Indonesia Tbk. (CPIN), (3) Gudang Garam Tbk. (GGRM), (4) Indofood Tbk. (INDF), (5) Indocement Tunggal Prakarsa Tbk. (INTP), (6) Japfa Comfeed Indonesia Tbk. (JPFA), (7) Kalbe Farma Tbk (KLBF), (8) Holcim Indonesia Tbk. (SMCB), and (9) Unilever Indonesia Tbk. (UNVR);

- from tertiary sector, the firm names are: (1) AKR Corporindo Tbk. (AKRA), (2) MNC Investama Tbk. (BHIT), (3) Sentul City Tbk. (BKSL), (4) Bumi Serpong Damai Tbk. (BSDE), (5) Ciputra Development Tbk. (CTRA), (6) Jasa Marga (Persero) Tbk. (JSMR), (7) Kawasan Industri Jababeka Tbk.(KIJA), (8) Lippo Karawaci Tbk. (LPKR), (9) Media Nusantara Citra Tbk. (MNCN), (10) Matahari Putra Prima Tbk. (MPPA), (11) Perusahaan Gas Negara (Persero) Tbk. (PGAS), (12) Summarecon Agung Tbk. (SMRA), (13) Telekomunikasi Indonesia (Persero) Tbk. (TLKM).

\subsection{Method of data collection}

The method of data collection is archival method. As stated by Hartono (2012), this method is suitable for the study using the secondary data. In this study, the secondary data are from the performance summary of the listed firms on Indonesia Stock Exchange.

Table 1. The number of sample and its allocation from the number of population based on stratified random sampling method

\begin{tabular}{l|c|c|c}
\hline \multicolumn{1}{c|}{ Stratum } & Number of population (N) & Percentage of allocation & Number of sample (n) \\
\hline Primary sector & 10 & $25 \%$ & $7,25 \approx 7$ (rounded) \\
Secondary sector & 12 & $30 \%$ & $8,70 \approx 9$ (rounded) \\
Tertiary sector & 18 & $45 \%$ & $13,05 \approx 13$ (rounded) \\
Total number of firms & 40 & $100 \%$ & 29 \\
\hline
\end{tabular}




\subsection{Method of data analysis}

The method of data analysis used is regression model with panel data. According to Widarjono (2013), panel data are defined as the combination between cross-sectional and time-series data. Based on information from sub-section 3.3, the number of cross-sectional data is $29 \mathrm{firms}$ and the number of time series data is 6 years.

The decision to use pooled regression model based on ordinary least square (common effect model) or fixed effect model is a essential issue to be solved in panel data regression. To achieve the best solution on this issue, the test of redundant fixed effect needs to be done (see Ghozali and Ratmono, 2013). The estimation of either common effect or fixed effect model is done by using ordinary least square (OLS) method, so that the tests related to classical assumptions, such as multicollinearity, heteroscedasticity, autocorrelation, and normality test, are still relevant (see Ghozali, 2016):

a) multicollinearity test is done to make sure that the significant relationship among independent variables does not exist, to show it, variance inflation factor (VIF) value of the independent variables is needed to be identified;

b) heteroscedasticity test is conducted to prove that the residuals $\varepsilon$ are not significantly affected by the independent variables in the model, to realize it, Harvey test is used;

c) autocorrelation test is done to prove residuals $\varepsilon$ have random pattern, to realize it, runs test on residuals is conducted;

d) normality test is done to prove that the residuals $\varepsilon$ are normally distributed, to realize it, one sample test of Kolmogorov-Smirnov is performed on residuals.

\section{RESULTS AND DISCUSSION}

This section describes some results such as classical assumption test, regression model estimation, hypotheses test, discussion, and managerial implication.

\subsection{The result of classical assumption test}

To become good regression model, set of the classical assumption tests is required to be fulfilled. The results related to the test can be performed as follows.

\subsubsection{The result of multicollinearity test}

To detect multicollinearity, the value of VIF for each independent variable is compared with 10 cut-off value (see Ghozali, 2016). Table 2 presents VIF value for BS, BI and DAR. In this table, it can be seen that the value of VIF for $\mathrm{BS}$ is 1.105, for $\mathrm{BI}$ is 1.071, and for DAR is 1.173 . Because these values are lower than 10 , multicollinearity does not exist.

Table 2. The detection of multicollinearity

\begin{tabular}{l|c|c} 
& \multicolumn{2}{c}{ Source: Modified output of IBM SPSS 20. } \\
\hline $\begin{array}{l}\text { Independent } \\
\text { variable }\end{array}$ & Collinearity statistics \\
\hline$B S$ & 0.905 & VIF \\
\hline$B I$ & 0.934 & 1.105 \\
\hline$D A R$ & 0.852 & 1.071 \\
\hline
\end{tabular}

\subsubsection{The result of heteroscedasticity test}

To prove that the residuals are not affected by the independent variables in the model, Harvey test is used. Residuals intended in this test are in logarithm of squared residuals (LRESID2). The result of this test can be seen in Table 3. In this table, probability value of Chi-square (3) of $\mathrm{Obs}^{\star} R$-squared is 0.0154 . Moreover, this value is compared with tightened $1 \%$ significant level. Because this value is higher than value of significance level, heteroscedasticity does not occur in this regression model.

\subsubsection{The result of autocorrelation test}

To prove the random pattern of residuals, runs test on residuals based on mode is conducted by comparing value of asymptotic significance (2-tailed) of $Z$-statistic with $5 \%$ significance level. The result of this test can be seen in Table 4. In this table, value of asymptotic significance (2-tailed) is 0.914 . Because this value is higher than $5 \%$ significance level, null hypothesis is accepted, so that residuals have random pattern. It means autocorrelation does not happen in this regression model. 
Table 3. The result of Harvey heteroscedasticity test

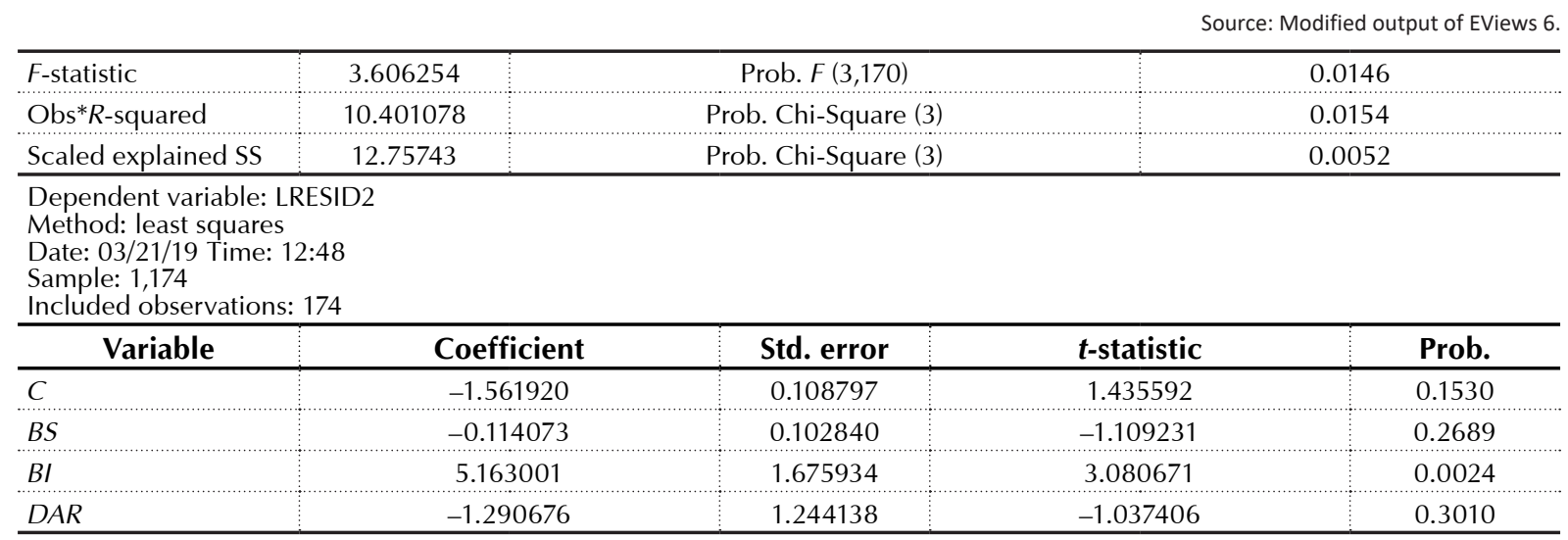

Table 4. The result of autocorrelation test

\begin{tabular}{l|c}
\multicolumn{1}{c|}{ Description } & $\begin{array}{c}\text { Source: Output of IBM SPSS } 19 . \\
\text { Unstandardized } \\
\text { residual }\end{array}$ \\
\hline Test value $^{\mathrm{a}}$ & $3.59231^{\mathrm{b}}$ \\
\hline Cases $<$ test value $^{\prime}$ & 173 \\
\hline Cases $\geq$ test value & 1 \\
\hline Total cases & 174 \\
\hline Number of runs & 3 \\
\hline Z & 0.108 \\
\hline Asymp. sig. (2-tailed) & 0.914 \\
\hline
\end{tabular}

Note: $\mathrm{a}$ - mode, $\mathrm{b}$ - multiple modes. The mode with the largest data value is used.

\subsubsection{The result of normality test}

To prove that the residuals are normally distributed, one sample test of Kolmogorov-Smirnov on residuals is conducted by comparing asymptotic significance (2-tailed) value of $Z$-statistic with $5 \%$ significance level. The result of normality test can be seen in Table 5. In this table, value of asymptotic significance (2-tailed) is 0.501 . Because this value is higher than $5 \%$ significance level, null hypothesis is accepted, so that residuals are normally distributed.

Table 5. Result of normality test

\begin{tabular}{|c|c|c|}
\hline \multicolumn{2}{|c|}{ Description } & $\begin{array}{l}\text { Unstandardized } \\
\text { residual }\end{array}$ \\
\hline \multicolumn{2}{|l|}{$N$} & 174 \\
\hline \multirow{2}{*}{$\begin{array}{l}\text { Normal } \\
\text { parameters }{ }^{\mathrm{a}, \mathrm{b}}\end{array}$} & Mean & 0.0000000 \\
\hline & Std. deviation & 0.157941767 \\
\hline \multirow{3}{*}{$\begin{array}{l}\text { Most extreme } \\
\text { differences }\end{array}$} & Absolute & 0.063 \\
\hline & Positive & 0.063 \\
\hline & Negative & -0.047 \\
\hline \multicolumn{2}{|c|}{ Kolmogorov-Smirnov $Z$} & 0.827 \\
\hline \multicolumn{2}{|c|}{ Asymp. sig. (2-tailed) } & 0.501 \\
\hline
\end{tabular}

Note: a - test distribution is normal, b - calculated from data.

\subsection{The estimation result of regression model}

After fulfilling the classical assumption tests, the next step is estimating the panel regression model. To select appropriate model, the test of redundant fixed effect needs to be performed by using the program EViews. This test functions to choose fixed effect or common effect model that will be conducted. Furthermore, the result of this test can be seen in Table 6 .

Table 6. Redundant fixed effects test result

Source: Output of EViews 9

Equation: EQ01

\begin{tabular}{c|c:c:c}
\hline \multicolumn{3}{c}{ Test cross-section fixed effects } \\
\hline \multicolumn{1}{c}{ Effects test } & Statistic & d.f. & Prob. \\
\hline Cross-section $F$ & 54.738170 & $(28,142)$ & 0.0000 \\
\hline $\begin{array}{l}\text { Cross-section } \\
\text { Chi-square }\end{array}$ & 429.352588 & 28 & 0.0000 \\
\hline
\end{tabular}

In Table 6, probability value of cross-section Chisquare statistic is 0.000 . This value is less than 0.05 significance level. It means that the null hypothesis stating that the fixed effect model is similar to common effect model is rejected. Therefore, fixed effect model is used. Furthermore, the estimation result of fixed effect regression model can be seen in Table 7.

\subsubsection{The result of hypotheses test}

The first hypothesis states that firm with large number of supervisory board members tends to have low value. This hypothesis is tested by com- 
Table 7. Estimation result of fixed regression model: the effect of supervisory board size and its independence and debt policy on firm value

Source: Modified output of EViews 9.

\begin{tabular}{l}
\hline Dependent variable: $L O G(P)$ \\
Method: panel least squares \\
Date: $03 / 21 / 19$ Time: $14: 32$ \\
\hline Sample: $2010-2015$
\end{tabular}

paring the probability value of $t$-statistic for BS with $5 \%$ significance level value. In Table 7 , the probability value intended is 0.1253 . Because this value is higher than that of significance level used, the first hypothesis is rejected. In other words, board size has no effect on firm value.

The second hypothesis consists of two sub-hypothesis. Sub-hypothesis 2a explains how board independence can own a positive effect on firm value. Sub-hypothesis $2 \mathrm{~b}$ explains the opposite impact of it on firm value. In Table 7, regression coefficient for $\mathrm{BI}$ shows a negative sign and its probability value of $t$-statistic is 0.0187 . Because this probability value is lower than that of 5\% significance level used, the sub-hypothesis $2 \mathrm{~b}$ is accepted. It means that board of independence has a negative impact on firm value.

The third hypothesis has two sub-hypotheses. The sub-hypothesis 3a explains how debt policy can have a positive effect on firm value. The sub-hypothesis $3 \mathrm{~b}$ explains how debt policy can have a negative effect on firm value. In Table 7, regression coefficient for DAR shows negative sign and its probability value of $t$-statistic is 0.0130 . This value is lower than that of $5 \%$ significance level, so that the sub-hypothesis $3 \mathrm{~b}$ is accepted. It means that debt policy has a negative impact on firm value.

\section{DISCUSSION}

The result of the first hypothesis testing shows supervisory board size has no effect on firm value. This condition shows ineffective actions of that board of commissioners as supervisory board to monitor activities of board of directors. According to Syakhroza (2005), these ineffective actions occur because the positions of these two boards are similar in Indonesia. They are appointed, replaced, and dismissed by general meeting of shareholders (see Indonesia Law of Limited Liability Company No. 40/2007 at Article 94 Section (1) and (5) for board of directors, as well as Article 111 Section (1) and (5) for board of commissioners). Therefore, this study confirms the result of the study of Yammeesri and Herath (2010), as well as Kritika and Choudhary (2015).

The result of the second hypothesis testing states that supervisory board independence has a negative effect on firm value. It means to create high firm value; shareholders have to appoint more members of inside supervisory board, because they can collaborate with board directors. Therefore, this study confirms result of the study of Ningtyas et al. (2014) and Rashid (2018) showing a negative effect of board independence on firm value.

The result of the third hypothesis testing states that debt policy has a significant negative effect on firm value. It means to increase their value in capital market, the firms are necessary to use less amount of debt in their capital structure by regularly paying for interest and principle to banks. By decreasing debt, the firms will be free from financial distress and bankruptcy. Therefore, this study confirms the result of the study of Paminto et al. (2016). 


\section{MANAGERIAL IMPLICATION}

Based on the test result of three hypotheses, some practical implications that can be generated are as follows:

1) firms are suggested that hiring inside supervisory board members to create alignment effect with director board members to gain its high value;

2) bankruptcy is the main issue of using debt; therefore, firm has to reduce the amount of debt to create the safe condition to increase its value.

\section{CONCLUSION AND RECOMMENDATIONS}

This research intends to test the effect of supervisory board existence and debt policy on firm value. The existence of supervisory board can be reflected by its size and independence. Based on the analysis conducted, it can be concluded that the number of supervisory board members has no effect on firm value, firm with high portion of independent supervisory board members and the amount of debt to finance total assets tends to create low value.

Based on the result of this study, some recommendations can be given to the next researchers who are interested in this research topic:

1) this study only uses two determinants related to board governance of firm value. The next researchers can add the other components of board governance that are expected to affect firm value, such as board duality, presence of audit committee, woman supervisory board, the number of supervisory board meeting;

2) this study only uses 6 years, started from 2010 until 2015, as time observation. The next researchers can extend time observation when they are going to do the study related to this topic. We suggest that the next researcher lengthen the time observation into 10 years.

\section{REFERENCES}

1. Badu, L. E. A., \& Apiah, K. O. (2017). Impact of Corporate Board Size on Firm Performance: Evidence from Ghana and Nigeria. Research in Business and Management, 4(2), 1-12. https:// doi.org/10.5296/rbm.v4i2.11721

2. Brealey, R. A., Myers, S. C., \& Allen, F. (2006). Corporate Finance (8th ed.). New York: McGraw-Hill.

3. Eisenberg, T., Sundgren, S., \& Wells, M. T. (1998). Larger board size and decreasing Firm value in Small Firms. Journal of Financial Economics, 48(1), 35-54. https://doi.org/10.1016/S0304405X(98)00003-8

4. FCGI (2001). The Roles of the Board of Commissioners and the
Audit Committee in Corporate Governance. Jakarta: Forum for Corporate Governance Indonesia.

5. Ghozali, I., \& Ratmono, D. (2013). Analisis Multivariat dan Ekonometrika: Teori, Konsep, dan Aplikasi dengan Eviews 8. Semarang: Badan Penerbit Universitas Diponegoro.

6. Ghozali, I. (2016). Aplikasi Analisis Multivariate dengan Program IBM SPSS 23. Semarang: BP-Universitas Diponegoro.

7. Gill, A., \& Mathur, N. (2011). Board Size, CEO Duality, and the Value of Canadian Manufacturing Firms. Journal of Applied Finance \& Banking, 1(3), 1-13. Retrieved from https://www.scienpress.com/ upload/jafb/vol\%201_3_1.pdf

8. Gunarso, P. (2014). Laba Akuntansi, Leverage, dan Ukuran Perusahaan Terhadap Harga Saham di Bursa Efek Indonesia. Jurnal Keuangan dan Perbankan, 18(1), 63-71. Retrieved from http://jurnal.unmer.ac.id/index. php/jkdp/article/view/773

9. Gitman, L. J., \& Zutter, C. J. (2012). Principles of Managerial Finance (13th ed.). Boston: Prentice Hall.

10. Hanafi, M. M. (2017). Manajemen Keuangan. Edisi Kedua, Badan Penerbit Fakultas Ekonomi Universitas Gadjah Mada, Yogyakarta. 
11. Hermawan, A. (2006). Penelitian Bisnis: Paradigma Kuantitatif. Penerbit PT Gramedia Widiasarana Indonesia, Jakarta.

12. Hartono, J. (2012). Metodologi Penelitian Bisnis: Salah Kaprah dan Pengalaman-Pengalaman. Edisi 6. Yogyakarta: BPFE-UGM.

13. Ibrahim, H., \& Salihu, A. M. (2015). Corporate Attribute of Board Size and Market Value of Firms in the Nigerian Chemical and Paints Industry. International Journal of Humanities and Social Science, 5(6), 101-108. Retrieved from https://www.ijhssnet. com/journals/Vol_5_No_6_ June_2015/13.pdf

14. IDX Fact Book (2016). Securities Indexes on Indonesia Stock Exchange. Research and Development Division of Indonesia Stock Exchange, Jakarta.

15. Isshaq, Z., Bokpin, G. A., \& Onumah, J. M. (2009). Corporate Governance, Ownership Structure, Cash Holdings, and Firm Value on The Ghana Stock Exchange. The Journal of Risk Finance, 10(5), 488-499. https://doi. org/10.1108/15265940911001394

16. Kangarlouei, S. J., Kavasi, B., \& Motavassel, M. (2013). The Effects of Outside board on Firm Value in Tehran Stock Exchange from The Perspective of Information Transaction Costs. International Journal of Industrial Mathematics, 5(4), 375-386. Retrieved from http://ijim.srbiau.ac.ir/article 2168.html

17. Kritika, \& Chodhary, V. (2015). Impact of Board Size on Firm Performance: A Study of Selected BSE500 Companies. Apeejay Journal of Management and Technology, 10(1), 34-40. Retrieved from https://apeejay.edu/aimtc/ aimtc-journal/docs/volume-10/ article-4.pdf

18. Kim, K. A., \& Nofsinger, J. R. (2007). Corporate Governance (2nd ed.). New Jersey: Pearson Education.

19. LaPorta, R., Lopez-de-Silanes, F., Shleifer, A., \& Vishny, R. (2000). Investor Protection and Corporate Governance. Journal of
Financial Economics, 58(1-2), 3-27. https://doi.org/10.1016/S0304405X(00)00065-9

20. Lipton, M., \& Lorsch, J. W. (1992). A Modest Proposal for Improved Corporate Governance. Business Lawyer, 48(1), 59-77. Retrieved from https://www.jstor.org/stable/ pdf/40687360.pdf?seq=1\#page_ scan_tab_contents

21. Nath, S. D., Islam, S., \& Saha, A. K. (2015). Corporate Board Structure and Firm Performance: The Context of Pharmaceutical Industry in Bangladesh. International Journal of Economics and Finance, 7(7), 106-115. https:// doi.org/10.5539/ijef.v7n7p106

22. Ningtyas, K. L., Suhadak, \& Nuzula, N. F. (2014). Pengaruh Good Corporate Governance Terhadap Nilai Perusahaan (Studi Pada Perusahaan Yang Terdaftar Di Jakarta Islamic Index Tahun 2010-2013). Journal Administration Bisnis, 17(1), 1-9. Retrieved from http://administrasibisnis.studentjournal.ub.ac.id/ index.php/jab/article/view/687

23. Mishra, R. K., \& Kapil, S. (2018). Effect of Board Characteristics on Firm Value: Evidence from India. South Asian Journal of Business Studies, 7(1), 41-72. https://doi. org/10.1108/SAJBS-08-2016-0073

24. Paminto, A., Setyadi, D., \& Sinaga, J. (2016). The Effect of Capital Structure, Firm Growth and Dividend Policy on Profitability and Firm Value of the Oil Palm Plantation Companies in Indonesia. European Journal of Business and Management, 8(33), 123-134. Retrieved from https:// iiste.org/Journals/index.php/ EJBM/article/view/33961

25. Rashid, A. (2008). Board independence and firm performance: Evidence from Bangladesh. Future Business Journal, 4(1), 34-49. https://doi. org/10.1016/j.fbj.2017.11.003

26. Sambora, M. N., Handayani, S. R., \& Rahayu, S. M. (2014). Pengaruh Leverage dan Profitabilitas Terhadap Nilai Perusahaan (Studi pada Perusahaan Food and Beverages yang terdaftar di BEI periode tahun 2009-2012). Jurnal Administrasi Bisnis, 8(1), 1-10.
Retrieved from https://administrasibisnis.studentjournal.ub.ac.id/ index.php/jab/article/view/364

27. Setiadi, I., Rahmawati, Sujardjanto, D., \& Djuminah (2017). Board Independence, Environmental Disclosure, and Firm Value.

Review of Integrative Business and Economics Research, 6(4), 409-417. Retrieved from https://sibresearch. org/uploads/3/4/0/9/34097180/ riber_6-4_32b17-172_409-417.pdf

28. Setiyawati, L., Wahyudi, S., \& Mawardi, W. (2017). The Influence of Dividend Policy, Debt Policy, Independent Commissioner, and Institutional Ownership on The Firm Value with Growth Opportunities as Moderator Variables (Study on Non-Financial Companies Listed On IDX in The Period of Years of 2012-2015). Jurnal Bisnis Strategi, 26(2), 146162. https://doi.org/10.14710/ jbs.26.2.146-162

29. Sugiarto (2009). Struktur Modal, Struktur Kepemilikan Perusahaan, Permasalahan Keagenan, dan Informasi Asimetri. Yogyakarta Cetakan Pertama, Graha Ilmu.

30. Sukamulja, S. (2002). Good Corporate Governance di Sektor Keuangan: Dampak GCG Terhadap Kinerja Perusahaan (Kasus Di Bursa Efek Jakarta). BENEFIT: Jurnal Manajemen dan Bisnis, 8(1), 1-25. Retrieved from http://journals.ums.ac.id/index. php/benefit/article/view/1193

31. Suliyanto (2009). Metode Riset Bisnis. Yogyakarta: Edisi Kedua, Penerbit Andi.

32. Syakhroza, A. (2005). Corporate Governance: Sejarah, Perkembangan, Teori Model, dan Sistem Governance serta Aplikasinya pada Perusahaan BUMN: Pidato Pengukuhan Guru Besar Tetap Pada Fakultas Ekonomi Universitas Indonesia. Jakarta Penerbitan: FE-UI.

33. Tjager, I. N., Alijoyo, F. A., Djemat, H. R., \& Soembodo, B. (2003). Corporate Governance: Tantangan dan Kesempatan Bagi Komunitas Bisnis Indonesia. Jakarta: PT Prenhalindo.

34. Waterings, J. P., \& Swagerman, D. M. (2012). The Impact of Board 
Investment Management and Financial Innovations, Volume 16, Issue 2, 2019

Size on Firm Value: Evidence from The Asian Real Estate Industry. Asian Journal of Business and Management Sciences, 1(8), 22-43. Retrieved from www.ajbms.org/ articlepdf/ajbms2011iii1727b.pdf

35. Widarjono, A. (2013).

Ekonometrika: Pengantar dan
Aplikasinya Disertai Panduan EViews. Edisi Keempat. Yogyakarta: UPP STIM YKPN

36. Yammeesri, J., \& Herath, S. K. (2010). Board Characteristic and Corporate Value: Evidence from Thailand. Corporate Governance: The International
Journal of Business in Society, 10(3), 279-292. https://doi. org/10.1108/14720701011051910

37. Yermack, D. (1996). Higher Market Valuation of Companies with a Small Board of Directors. Journal of Financial Economics, 40(2), 185211. https://doi.org/10.1016/0304405X(95)00844-5 